\title{
Comparative work values among future managers in China and the USA
}

Article in International Journal of Chinese Culture and Management · January 2008

DOI: 10.1504/IJCCM.2008.017168

CITATIONS

0

4 authors, including:

\section{John Alan Parnell}

University of North Carolina at Pembroke 130 PUBLICATIONS $\quad 2,007$ CITATIONS

SEE PROFILE
READS

42

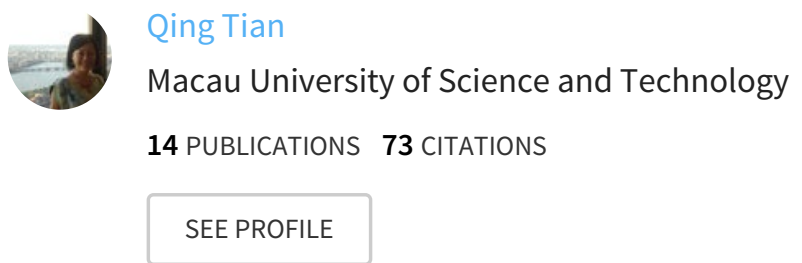

Some of the authors of this publication are also working on these related projects:

Project $\quad$ Firm Performance View project

Project Corporate social responsibility, ethical climate, employee voluntary behavior View project 


\title{
Comparative work values among future managers in China and the USA
}

\author{
John A. Parnell* \\ School of Business \\ University of North Carolina-Pembroke \\ Pembroke, NC 28372, USA \\ E-mail: john.parnell@uncp.edu \\ *Corresponding author \\ Qing Tian \\ Faculty of Management and Administration \\ Macau University of Science and Technology \\ Avenida Wai Long, Taipa, Macao \\ E-mail: zjtianqing@yahoo.com
}

\section{Alexander Nai-Chi Chen}

Macau University of Science and Technology

Avenida Wai Long, Taipa, Macao

E-mail: ncchen@must.edu.mo

\section{Ting Yu}

School of Finance and Economics

Ling Tung University

1 Ling Tung Road

Taichung City, Taiwan

E-mail: yutingdoc@yahoo.com

\begin{abstract}
Work values have been identified as critical variables in the career development process. Many of the problems associated with foreign joint ventures in China over the past two decades have been concerned with employee motivation and retention. Given these concerns, it is important to examine how differences between future managers in China and the USA might be changing over the past decade. This paper considers whether or not there are significant differences in work value among management students in US and Chinese business schools. Utilising Manhardt's work values instrument, US business students were found to be concerned more with competence and growth than Chinese business students, but no differences were found along the factors of comfort and security, and status and independence.
\end{abstract}

Keywords: work values; China; Chinese culture; US culture; Manhardt.

Reference to this paper should be made as follows: Parnell, J.A., Tian, Q., Nai-Chi Chen, A. and $\mathrm{Yu}, \mathrm{T}$. (2008) 'Comparative work values among future managers in China and the USA', Int. J. Chinese Culture and Management, Vol. 1, No. 2, pp.144-156. 
Biographical notes: John A. Parnell presently serves as the William Henry Belk Professor of Management at the University of North Carolina at Pembroke. He is the author of over 200 basic and applied research articles, published presentations, and cases in strategic management and related areas. He earned the BSBA, MBA, and MA degrees from East Carolina University, the EdD degree from Campbell University, and the $\mathrm{PhD}$ degree in Strategic Management from The University of Memphis. He has authored textbooks in strategic management and organisational theory, and his research interests include business strategies, crisis management, and sustainable strategic management.

Qing Tian is an Assistant Professor at Macao University of Science and Technology in China. Dr. Tian earned her Masters and PhD degrees from the University of Kiel in Germany. Her work has been published in international journals such as Journal of Business Ethics. Her research interests include organisational behaviour, business ethics, and cross-cultural management.

Alexander Nai-Chi Chen currently serves as the Registrar and Professor of Management at Macau University of Science and Technology. Dr. Chen previously served on the faculties of Penn State University at Altoona and the University of North Carolina at Pembroke. He has published numerous papers in management information systems, and his current work emphasises cross-cultural management and entrepreneurship. He received his Bachelor's degree from National Taiwan University and his Masters and $\mathrm{PhD}$ degrees from Penn State University.

Ting Yu currently serves as Assistant Professor and Chairman of Department of Accounting and Information Technology at Ling Tung University in Taiwan. He earned the BBA degree from Chung Yuan Christian University (CYCU) in Taiwan, the Masters of Accounting and Financial Information System degree from Cleveland State University, and the Doctor of Management degree from Webster University. His research interests include management accounting, strategic cost management, enterprise resource planning, and corporate governance.

\section{Introduction}

Nations classified as transition economies currently offer the greatest business opportunities in the world. China, the largest such society, has enjoyed a tremendous amount of development and success in recent years. However, a great deal of uncertainty remains among Western business leaders concerning the Chinese marketplace and Chinese management practices (Chong-Yah, 2003; Peng et al., 2003). Differences in work values - particularly between China and the USA - have been cited as a key concern (Takeuchi et al., 2003).

Work values have been identified as critical variables in the career development process and influence job tenure (Super and Sverko, 1995). Many of the problems associated with foreign joint ventures in China over the past two decades have been linked to motivation and retention for both employees and managers (Child, 1994; Lu, 1998; Wang and Zatow, 1994; Takeuchi et al., 2003). If Western firms are to enhance management practice in China, they must understand the differences in work values between managers and workers in China and those in the West. 
Given recent economic and cultural changes, and the shortage of managers in emerging regions of Asia, examining the work values of future managers is important for multinational corporations wishing to implement more effective international management programmes in China. In addition, understanding how national culture may influence one's perception of work value becomes important as business organisations adopt a global perspective. While examining the work values of US and Chinese business students from a comparative point of view, this study also attempts to ask whether such situations as economic prosperity and globalisation might mitigate the impact of national cultures on work values.

\section{Theoretical background and hypotheses}

The term 'work values' has been used interchangeably with term such as 'work goals' and 'job orientations' (Ros et al., 1999; Manhardt, 1972). Work values represent those values that individuals believe should be satisfied as a result of their participation in the work role. They guide individuals' work achievement, responsibility, their life and wealth expectations and also influence individuals' work commitment and job satisfaction (Kalleberg, 1977; Kanchier and Wally, 1989; Loscocco, 1989). As such, work values are critical determinants in job development and retention.

Measuring work values is not easy, however. Some researchers suggest that Western notions of motivation and work values may not be applicable in China (Jackson and Bak, 1998) and Chinese applications of western survey instruments such as scales utilised in the present study have their limitations or restrictions (Jamal, 1999; Harrison et al., 2000). However, other researches suggest the contrary. These Western concepts have been helpful in identifying significant differences in values, especially using the Chinese Value Survey developed by Bond (1987) among managers in the USA, Mainland China and Hongkong (Ralston et al., 1997). The only non-matching dimension in Bond's study was the Chinese concept of Confucian dynamism. Recent evidence also suggests that Chinese managers in some industries give high importance to such matters as high earnings, pleasant working conditions, (Wong and Chung, 2003) and other extrinsic work values like their Western counterparts (White, 2005).

In this regard, this study seeks to measure the job orientation differences based on different cultures using Manhardt's (1972) three dimensions of work values: comfort and security, competence and growth, and status and independence. In addition, this study also tests the applicability of this scale measuring work values in China. The first dimension of comfort and security includes job security, ample leisure time off the job and comfortable working conditions. It was considered as physiological and safety needs in Maslow's (1954) five needs taxonomy and as extrinsic factor leading to job dissatisfaction in Herzberg's two-factor theory (Herzberg et al., 1959). The second dimension, competence and growth, includes such items as feelings of accomplishment, autonomy, creativity provided by the job, self-actualisation, and achievement. These are related to job satisfaction in Herzberg's intrinsic reward scenario, including factors such as autonomy, creativity, and responsibility. The third dimension, status and independence, refers to career success such as esteem, compensation and upward striving, which are analogous to extrinsic motivating factors (Herzberg et al., 1959). Extrinsic work values are in the form of rewards such as salary, opportunity for promotion and extrinsic social conditions such as supervisory relationships (Meyer et al., 1998). 
An individual's attitudes and values are, to a large extent, shaped by culture. Hofstede's (1991) cultural dimensions are a useful tool to clarify the differences between China and the USA (see Table 1). Where countries differ on one or more of these dimensions, work values of the members of these cultures may also differ.

Table 1 Cultural typology: China versus the USA

\begin{tabular}{lccccc}
\hline Country & $\begin{array}{c}\text { Power } \\
\text { distance }\end{array}$ & Individualism & Masculinity & $\begin{array}{c}\text { Uncertainty } \\
\text { avoidance }\end{array}$ & $\begin{array}{c}\text { Confucian } \\
\text { dynamism }\end{array}$ \\
\hline China & 80 & 20 & Score & & \\
USA & 40 & 91 & 50 & 60 & 118 \\
\hline
\end{tabular}

Source: Hofstede (1991)

\subsection{Work environment}

Considering Hofstede's Uncertainty Avoidance (UA) dimension, the USA has a low index value and China has a high value. In low UA societies such as the USA, people feel less threatened by ambiguity and are willing to take risks in life, recognising that the future is unpredictable. In contrast, individuals in high UA societies like China are more concerned with security in life, and prefer clear hierarchical structures in organisations. They feel a greater need for written rules and procedures, and are intolerant of deviations from standard practices. In high UA countries, various rules and norms that reduce this uncertainty are to be expected. Its members prefer rules and long-term stable situations. Not surprisingly, Chinese students often demonstrate a stronger need for task simplicity and predictability (Bu and McKeen, 2001). This suggests that in a culture of high level of uncertainty avoidance such as China, workers are more likely to prefer an organisation with clear-cut rules and procedures to follow. They tend to accept such jobs permit a regular routine in time and place of work. Thus, we propose:

\section{H1 Chinese students will place a greater emphasis than US students on comfort and security}

\subsection{Self-actualisation}

In comparison to China, US culture is strong in individualism (see Table 1). The individualism-collectivism cultural dimension is used to measure the extent to which a culture values individual achievement rather than emphasising the interests of the group (Hofstede, 1980). In US societies, personal achievement is recognised culturally with rewards for competing within groups. In US value systems, a greater emphasis is placed on competition and achievement. In collectivist societies such as China, people are more likely to see themselves as benefiting from the group and are recognised for sacrificing personal interest to collective goals (Hofstede and Bond, 1988).

These differences suggest that Americans tend to think of themselves more as ' $I$ ' and tend to classify themselves and each other by individual characteristics rather than by group membership. Individualists believe that the self is the basic unit of survival and have high needs for autonomy (Hui, 1988). According to Manhardt (1972), Americans 
are more likely to pursue a job that requires originality and creativity, satisfies aesthetic interests, and permits individuals to develop their own methods of completing job tasks. High individualistic groups manifest greater assertiveness in meeting personal objectives and needs, such as the desire to actualise one's gifts and abilities (Hofstede, 1980). The dimension of intrinsic rewards contained items related to autonomy and self-actualisation (Bu and McKeen, 2001). A number of studies demonstrate that employees in individualistic cultures such as the USA tend to emphasise individual career success and the satisfaction of the intrinsic need for self-actualisation, while employees in collectivistic cultures such as China tend to focus on work atmosphere or environments (Dunphy and Shi, 1989; Hui and Tan, 1996; Pelled and Xin, 1997; Bu and McKeen, 2001). Hence, we propose:

\section{H2 US students will place a greater emphasis than Chinese students on competence and growth}

\subsection{Career success}

Status and Independence is classified by Manhardt (1972) as career success and includes esteem, promotion opportunities and high income, factors often associated with career success by many university graduates. Hofstede's Masculinity Index measures the extent to which the dominant values in a society are 'masculine'. Members of such societies tend to be more assertive, more concerned with the acquisition of material goods, and less concerned with others in the society. In addition, they usually regard high earnings as symbols of career success (Manhardt, 1972). Societies whose members are less assertive, less concerned with the acquisition of material goods, and more concerned with others are called 'feminine' cultures (Hofstede, 1984).

Hofstede's concept of masculinity in China is lower than that in the USA, suggesting that US management students tend to place more emphasis on personal goals such as advancement and high income. In the Chinese culture, individuals tend to show greater concern to personal goals such as a friendly atmosphere and getting along well with one's immediate superior and fellow workers. The concept of power distance is much more pronounced in Chinese society than in the USA (Hofstede, 1980; 1991; 1993). Hofstede also found that US workers may be more inclined to approach a superior and less likely to accept their superiors' questionable practices than workers in China.

Chinese workers and managers typically are much more aware and respectful of formal hierarchies than their US counterparts. In China, information is closely held and decisions are not frequently challenged. Decisions are made at the top ( $\mathrm{Lu}$, 1998; Scarborough, 1998), and interaction among individuals and organisations is built upon trust and is highly personalised (Schermerhorn and Bond, 1992). As such, participative management approaches are not as common (Pun et al., 2000; Redding and Richardson, 1986; Westwood, 1997). Chinese managers tend to be more people- and relationship-oriented than US managers (Lockett, 1988; Wah, 2001). As a result, we propose the following hypothesis to measure the subscale of Status and Independence:

H3 US students will place a greater emphasis than Chinese students on status and independence 


\section{Methods}

Twenty-one statements about work goals were derived from Manhardt's (1972) classic work values scale and slightly changed (Brenner and Tomkiewicz, 1982; Bu and McKeen, 2001). The survey was designed to measure job orientation of the business students from the USA and China. It was administered in English to US students and in Chinese to students in China. The Chinese questionnaire was translated into English by bilingual professionals from US and Chinese business schools.

Work values were measured via Manhardt's (1972) three-dimensional work values scale consisting of (1) comfort and security, (2) competence and growth, and (3) status and independence. A five-point Likert scale ranging from 5 (very important) to 1 (unimportant) was used to evaluate the work values of US and Chinese business students. Manhardt's (1972) work values scale, separate factor analyses were applied to the first five items (comfort and security), the next nine items (competence and growth), and the final seven items (status and independence).

A total of 634 business students - 308 from southern Mainland China and 326 from four public universities across the southern and southwestern USA - were surveyed about their work values. The target respondents were senior undergraduate and postgraduate students.

\section{Findings}

Factor loadings for the US students support the reliability of the scale, with the exception of three marginal items. 'Provides ample leisure time off the job' produced a loading of .478 , 'requires supervising others' generated a loading of .455 , and 'permits working independently' produced a loading of .499. Coefficient alphas were $.651, .829$, and .713 for the three scales respectively (see Table 2).

Factor loadings for the Chinese sample also support the reliability of the scale. Two marginal items existed in the status and independence subscale, however. One item, 'provides the opportunity to earn a high income', produced a loading of only .493 . Another item, 'permits working independently' produced a loading of .419. Coefficient alphas of the Chinese sample were .711, .762 and .712 respectively (see Table 3).

Factor scores were computed to serve as composite measures for the three scales of work values to the three hypotheses. Variance analysis indicates there exists significant differences in one of the work value variables - competence and growth - between US and Chinese business students (see Table 4).

Results were mixed. Based on the factor and variance analysis, Hypothesis 1 was not supported. No significant differences were found along comfort and security between US and Chinese students. Hypothesis 2 was supported. US students placed a greater emphasis than their Chinese counterparts on competence and growth. Hypothesis 3 was not supported. No significant differences were found along status and independence between US and Chinese business students. 
Table 2 Results of factor analyses, US students $(\mathrm{n}=326)$

\begin{tabular}{|c|c|}
\hline Item & $\begin{array}{c}\text { Subscale factor } \\
\text { loading }\end{array}$ \\
\hline \multicolumn{2}{|l|}{ Comfort and security subscale $($ alpha $=.651)$} \\
\hline Permits a regular routine in time and place of work & 677 \\
\hline Provides job security & .711 \\
\hline Has clear-cut rules and procedures to follow & .746 \\
\hline Provides ample leisure time off the job & .478 \\
\hline Provides comfortable working conditions & 639 \\
\hline Eigenvalue & 2.155 \\
\hline Percentage of variance explained & $43.1 \%$ \\
\hline \multicolumn{2}{|l|}{ Competence and growth subscale $($ alpha $=.829)$} \\
\hline Requires meeting and speaking with many other people & .598 \\
\hline Is intellectually stimulating & 613 \\
\hline Requires originality and creativity & .732 \\
\hline Makes a social contribution by the work you do & 659 \\
\hline Satisfies your cultural and aesthetic interests & .668 \\
\hline Encourages continued development of knowledge and skills & .705 \\
\hline Permits you to develop your own methods of doing the work & .634 \\
\hline Provides a feeling of accomplishment & 662 \\
\hline Provides change and variety in duties and activities & 603 \\
\hline Eigenvalue & 3.852 \\
\hline Percentage of variance explained & $42.8 \%$ \\
\hline \multicolumn{2}{|l|}{ Status and independence subscale $($ alph $a=.713)$} \\
\hline Permits advancement to high administrative responsibility & .742 \\
\hline Provides the opportunity to earn a high income & .594 \\
\hline Requires supervising others & .455 \\
\hline Permits working independently & .499 \\
\hline Is respected by other people & 695 \\
\hline Requires working on problems on central importance to the organisation & .706 \\
\hline Gives you the responsibility for taking risks & .663 \\
\hline Eigenvalue & 2.779 \\
\hline Percentage of variance explained & $39.7 \%$ \\
\hline
\end{tabular}


Table 3 Results of factor analyses, Chinese students $(n=308)$

\begin{tabular}{|c|c|}
\hline Item & $\begin{array}{l}\text { Subscale factor } \\
\text { loading }\end{array}$ \\
\hline \multicolumn{2}{|l|}{ Comfort and security $($ alpha $=.711)$} \\
\hline Permits a regular routine in time and place of work & 625 \\
\hline Provides job security & .772 \\
\hline Has clear-cut rules and procedures to follow & .656 \\
\hline Provides ample leisure time off the job & 670 \\
\hline Provides comfortable working conditions & .701 \\
\hline Eigenvalue & 2.359 \\
\hline Percentage of variance explained & $47.2 \%$ \\
\hline \multicolumn{2}{|l|}{ Competence and growth $(a l p h a=.762)$} \\
\hline Requires meeting and speaking with many other people & .541 \\
\hline Is intellectually stimulating & .678 \\
\hline Requires originality and creativity & .658 \\
\hline Makes a social contribution by the work you do & .513 \\
\hline Satisfies your cultural and aesthetic interests & .505 \\
\hline Encourages continued development of knowledge and skills & .600 \\
\hline Permits you to develop your own methods of doing the work & .566 \\
\hline Provides a feeling of accomplishment & 606 \\
\hline Provides change and variety in duties and activities & 660 \\
\hline Eigenvalue & 3.186 \\
\hline Percentage of variance explained & $35.4 \%$ \\
\hline \multicolumn{2}{|l|}{ Status and independence (alpha $=.712$ ) } \\
\hline Permits advancement to high administrative responsibility & 607 \\
\hline Provides the opportunity to earn a high income & .493 \\
\hline Requires supervising others & .738 \\
\hline Permits working independently & .419 \\
\hline Is respected by other people & .536 \\
\hline Requires working on problems on central importance to the organisation & .774 \\
\hline Gives you the responsibility for taking risks & 646 \\
\hline Eigenvalue & 2.637 \\
\hline Percentage of variance explained & $37.7 \%$ \\
\hline
\end{tabular}


Table 4 Anova results

\begin{tabular}{lcccc}
\hline Scale & US mean & Chinese mean & F-value & Significant level \\
\hline Comfort and security & 4.05 & 4.09 & 1.037 & .309 \\
Competence and growth & 3.84 & 4.06 & 25.591 & .000 \\
Status and independence & 3.90 & 3.97 & 2.516 & .113 \\
\hline
\end{tabular}

\section{Discussion}

The present study supported the validity of all three of Manhardt's (1972) work value subscales: comfort and security, competence and growth, and status and independence. Interpretations of Chinese students' responses appear to be reasonably valid when related to US work values. No significant differences were found along comfort and security, and status and independence, but US students reported a greater emphasis on competence and growth than their Chinese counterparts. The Chinese responses did not differ significantly from US conceptualisation of work values, except along the subscale of competence and growth.

The lack of significant differences between US and Chinese students in comfort and security, and status and independence runs counter to conventional wisdom concerning differences between US and Chinese managers and students. The comfort and security dimension included items of comfortable working conditions and job security, which were considered as physiological and safety needs in Maslow's taxonomy. Chinese workers are motivated by the goal of satisfying self-interests, which has been well articulated by Maslow and other Western scholars (Kao and Ng, 1997). This result suggests that differences in work values between China and Western countries may be diminishing with the current generation of students.

Researchers have questioned the applicability of scales measuring western work value in China based on cultural differences. Such thinking, however, has been based on the analysis of various Chinese groups. As the spread of market-based economics has influenced the cultural environment of China, Chinese values, especially those in young generations, appear to be changing. Traditional Chinese values are straining under the pressure of change, urbanisation and development. Such changes can be observed from the typical Chinese lifestyle where cultural and economic values are being renegotiated. Most studies on Chinese values by Western researchers concentrate on traditional Chinese values such as Confucianism and Daoism. Nevertheless, a mere knowledge of Chinese traditional philosophies provides only a limited access to a complete understanding of Chinese characteristics and tendencies (Tian, 2004). The traditions and culture of China are changing and in many ways are becoming more global.

The lack of significant differences along comfortable and secure working conditions, and status and independence between the two cultures suggests that student culture may be defined significantly by values associated with one's field of study - management - and not solely by national influences. Hence, in the field of management, US students and Chinese students may share some commonalities in work goals, needs and values. While national culture plays a crucial role in business and influencing people' work values, commonalities in work values probably exist between US and Chinese people. 
These situational factors mitigating the impact of national cultures on work values, such as generation change, globalisation, and effective communication, etc., should also be considered. Along these lines, Chinese and US students expressed equal attention to work values, regardless of national culture differences. Meanwhile, Chinese students appear to find their identities in economic transition as never before.

However, this study identified significant differences along the work value of competence and growth for US and Chinese students. Despite the diminishing differences of work values of comfort and security, and status and independence between the business students of America and Mainland China, the attitude towards competence and growth is the exception. Along these lines, Chiu et al. (1998) studied Chinese managers with regard to aggression and found the Chinese tend to avoid assertive and competitive behaviour, as such behaviour of challenging and competition is thought to cause conflict and lack of harmony. Modesty and concern for interpersonal relationships are highly appreciated in the workplace.

As aforementioned, Chinese culture tend to emphasise collectivism rather than individualism. High collectivism can hinder and reject individualism in its culture by the way of rejecting individual innovation and creativity. Thus, individuals in collectivist cultures like China are more likely to make decisions as a team. It is possible, however, that such dependence on groups might hinder one's innovative spirit.

\section{Conclusions and future research}

This study demonstrated both similarities and differences among US and Chinese management students. US business students were found to be concerned more with competence and growth than Chinese business students, but no differences were found along comfort and security, and status and independence.

A number of challenges remain. First, the application of Western scales to non-Western samples remains a conundrum (Peng et al., 2001), and the present study was no exception. When scales are not translated to account for language and cultural differences for generalisability sake, scale reliabilities often suffer as a result. Alternatively, researchers may choose to develop instruments from indigenous Chinese values (e.g., Fahr et al., 1987; 1998) to maximise measurement precision. However, when scales are translated and/or modified to address cultural differences, then direct comparisons between distinct cultural groups are tenuous at best. Solving this dilemma is not easy. Fortunately, however, the present study suggests that the complexity of this problem may be diminishing amidst generational changes, at least to some extent.

Second, a number of work value differences between China and the USA that are associated with management practice have been identified (Peng et al., 2001). The present study examined only those linked to Manhardt's original work, however. For example, Ralston and Gustafson (1993) identified a slightly different list of Chinese managerial values that distinguish Chinese managers from their Western counterparts: Confucian work dynamism, human-heartedness, integration, and moral discipline. Nepotism and paternalism also dominate the leadership orientation of most Chinese managers (Bond and Kwang-Hu, 1986; Redding, 1980). Many Chinese businesses are family-oriented, with an organisational structure and behavioural patterns that typically resemble a family model (Wah, 2001). Even in large Chinese organisations, the sense of 
an individual's loyalty to the manager and the organisation, as well as a manager's loyalty to his or her subordinate, tends to be much more prominent. Additional studies that consider alternative conceptualisations of work values and approaches will be useful.

Finally, little is known about the prospective role of the Internet in changing managerial perceptions of Chinese management students. Chinese Internet usage patterns are differ dramatically from their Western counterparts. The Chinese government is a strong supporter of Internet usage. Most government agencies have web pages, although they primarily provide information and are not utilised to conduct business, and state-owned China Telecom has reduced its Internet access fees considerably since 1997 (Hachigian, 2001). The Chinese government is sensitive to the use of the Internet as an effective medium of state opposition, however (Yang, 2001). Net executives in China seek to adhere to local customs, a practice the many critics interpret as voluntary censorship (Yee, 2001). This influence on changing Chinese culture is significant and warrants further investigation.

\section{References}

Bond, H.M. and Kwang-Hu, H. (1986) The Psychology of Chinese, The Psychology of the Chinese People, in M.H. Bond (Ed.) Hong Kong: Oxford.

Bond, M.H. (1987) 'Intergroup relations in Hong Kong: the Tao of stability', in J. Boucher, D. Dandis and K.A. Clark (Eds.) Ethnic Conflict: International Perspectives, Newbury Park, CA: Sage, pp.55-78.

Brenner, O.C. and Tomkiewicz, J. (1982) 'Job orientation of black and white college graduates', Personnel Psychology, Vol. 35, pp.89-103.

$\mathrm{Bu}, \mathrm{N}$. and McKeen, C.A. (2001) 'Work goals among male and female business students in Canada and China: the effects of culture and gender', International Journal of Human Resource Management, Vol. 12, No. 2, pp.166-183.

Child, J. (1994) Management in China During the Age of Reform, Cambridge, UK: Cambridge University Press.

Chiu, R.K., Wong, N.M. and Kosinski, F.A. (1998) 'Confucian values and conflict behavior of Asian managers: a comparison of two countries', Social Behavior and Personality, Vol. 26, No. 1, pp.11-22.

Chong-Yah, L. (2003) 'New growth theory and the ascendancy of China', Nanyang Business Review, Vol. 2, No. 2, pp.67-74.

Dunphy, D. and Shi, J. (1989) 'A comparison of enterprise management in Japan and China', in C.A.B. Oswigweh (Ed.) Organizational Science Abroad, New York: Plenum Press.

Fahr, J-L., Podsakoff, P. and Cheng, B-S. (1987) 'Culture-free leadership effectiveness versus moderators of leadership behavior: an extension and test of Kerr and Jermiers substitutes for leadership model in Taiwan', Journal of International Business Studies, Vol. 18, pp.43-60.

Fahr, J-L., Tsui, A., Xin, K. and Cheng, B-S. (1998) 'The influence of relational demography and guanxi: the Chinese case', Organization Science, Vol. 9, pp.471-488.

Hachigian, N. (2001) 'Chinas cyber-strategy', Foreign Affairs, Vol. 80, No. 2, pp.118-133.

Harrison, G.L., McKinnon, J.L., Wu, A. and Chow, C.W. (2000) 'Cultural differences on adaptation to fluid workgroups and teams', Journal of International Business Studies, Vol. 31, pp.489-505.

Herzberg, F., Mausner, B. and Snyderman, B. (1959) The Motivation to Work, New York: Wiley.

Hofstede, G. (1980) Cultures Consequences: International Differences in Work-related Values, London: Sage Publications. 
Hofstede, G. (1984) 'The cultural relativity of the quality of life concept', Academy of Management Review, Vol. 9, pp.389-398.

Hofstede, G. (1991) Cultures and Organization: Software of the Mind, New York: McGraw Hill.

Hofstede, G. (1993) 'Cultural constraints in management theories', Academy of Management Executive, Vol. 7, No. 1, pp.81-94.

Hofstede, G. and Bond, M. (1988) 'The Confucius connection: from cultural roots to economic growth', Organizational Dynamics, Vol. 16, No. 4, pp.5-21.

Hui, C.H. (1988) 'Measurement of individualism-collectivism', Journal for Research on Personality, Vol. 22, pp.17-36.

Hui, C.H. and Tan, C.K. (1996) 'Employee motivation and attitudes in the Chinese workforce', in M.H. Bond (Ed.) The Handbook of Chinese Psychology, Hong Kong: Oxford University Press.

Jackson, T. and Bak, M. (1998) 'Foreign companies and Chinese workers: employee motivation in the Peoples Republic of China', Journal of Communication Management, Vol. 11, No. 4, pp.282-300.

Jamal, M. (1999) 'Job stress, type a behavior, and well-being: a cross-cultural examination', International Journal of Stress Management, Vol. 6, pp.57-67.

Kalleberg, A.L. (1977) 'Work values and job rewards: a theory of job satisfaction', American Sociological Review, Vol. 42, No. 1, pp.124-143.

Kanchier, C. and Wally, R.U. (1989) 'Factors influencing career changes', International Journal for Achievement of Counseling, Vol. 12, No. 4, pp.309-321.

Kao, H.S.R. and Ng, S-H. (1997) Work Motivation and Culture, Motivation and Culture, New York: Routledge.

Lu, X. (1998) 'An interface between individualistic and collectivistic orientations in Chinese cultural values and social relations', The Howard Journal of Communications, Vol. 9, pp.91-107.

Lockett, M. (1988) 'Culture and the problems of Chinese management', Organisation Studies, Vol. 914, pp.475-496.

Loscocco, K. (1989) 'The instrumentally oriented factory worker: myth or reality?', Work and Occupations, Vol. 16, No. 1, pp.3-25.

Manhardt, P.J. (1972) 'Job orientation of male and female college graduates in business', Personnel Journal, Vol. 25, pp.361-368.

Maslow, A.H. (1954) Motivation and Personality, New York, NY: Harper \& Row.

Meyer, J.P., Irving, G.P. and Allen, N.J. (1998) 'Examination of the combined effects of work values and early work experiences on organizational commitment', Journal of Organizational Behavior, Vol. 19, No. 1.

Pelled, L.H. and Xin, K.R. (1997) 'A theoretical examination of work values in China, Mexico and the United States', Journal of Applied Management Studies, Vol. 6, No. 2, pp.185-198.

Peng, M.W., Lu, Y., Shenkar, O. and Wang, D.Y.L. (2001) 'Treasures in the China house: a review of management and organizational research on Greater China', Journal of Business Research, Vol. 52, pp.95-110.

Peng, Z., Priem, R.L. and Berg, D.M. (2003) 'Gradual marketization in the Peoples Republic of China: building an institutional environment for entrepreneurship and innovation', Nanyang Business Review, Vol. 2, No. 2, pp.75-91.

Pun, K-F., Chin, K-S. and Lau, H. (2000) 'A review of the Chinese cultural influences on Chinese enterprise management', International Journal of Management Reviews, Vol. 2, pp.325-338.

Ralston, D.A. and Gustafson, D.J. (1993) 'Differences in managerial values: a study of U.S., Hong Kong, and PRC managers', Journal of International Business Studies, Vol. 24, pp.249-276. 
Ralston, D.A., Holt, D.H., Terpstra, R.H. and Yu, K.C. (1997) 'The impact of national culture and economic ideology on managerial work values: a study of the United States, Russia, Japan, and China', Journal of International Business Studies, Vol. 28, pp.197-207.

Redding, S.G. (1980) 'Cognition as an aspect of culture and its relation to management process: an exploratory view of the Chinese case', Journal of Management Studies, Vol. 17, No. 2, pp.127-148.

Redding, S.G. and Richardson, S. (1986) 'Participative management and its varying relevance in Hong Kong and Singapore', Asia Pacific Journal of Management, Vol. 3, No. 1, pp.76-98.

Ros, M., Schwartz, S. and Surkiss, S. (1999) 'Basic individual values, work values, and the meaning of work', Applied Psychology: An International Review, Vol. 48, pp.49-71.

Scarborough, J. (1998) 'Comparing Chinese and Western cultural roots: why "East is East and...", Business Horizons, Vol. 41, No. 6, pp.15-24.

Schermerhorn, J. and Bond, H.M. (1992) 'Upward and downward influence tactics in managerial networks: a comparative study of Hong Kong Chinese and Americans', Asia Pacific Journal of Management, Vol. 8, pp.147-158.

Super, D.E. and Sverko, B. (Eds.) (1995) Life Roles, Values and Careers: International Findings of the Work Importance Study, San Francisco: Jossey-Bass.

Takeuchi, N., Wakabayashi, M. and Chen, Z.G. (2003) 'The strategic HRM configuration for competitive advantage: evidence from Japanese firms in China and Taiwan', Asia Pacific Journal of Management, Vol. 20, No. 4, pp.447-480.

Tian, Q. (2004) A Transcultural Study of Ethical Perceptions and Judgments Between Chinese and German Businessmen, Martin Meidenbauer, Verlagsbuchhandlung $\mathrm{GmbH} \& \mathrm{Co} \mathrm{KG}$, Muenchen, ISBN 3-89975-497-2, Germany.

Wah, S.S. (2001) 'Chinese cultural values and their implication to Chinese management', Singapore Management Review, Vol. 23, No. 2, pp.75-83.

Wang, Z.M. and Zatow, T. (1994) 'Leadership styles and organizational effectiveness in Chinese-Japanese joint ventures', Journal of Managerial Psychology, Vol. 9, No. 4, pp.31-36.

Westwood, R. (1997) 'Harmony and patriarchy: the cultural basis for paternalistic "headship" among the overseas Chinese', Organization Studies, Vol. 18, pp.445-448.

White, C. (2005) 'The relationship between cultural values and individual work values in the hospitality industry', International Journal of Tourism Research, Vol. 7 , Nos. 4-5, pp.221-229.

Wong, C.S. and Chung, K.M. (2003) 'Work values of Chinese food service managers', International Journal of Contemporary Food Service Management, Vol. 15, No. 2, pp.66-75.

Yang, D.Y. (2001) 'The great net of China: internet technology and governance in China', Harvard International Review, Winter, pp.64-69.

Yee, C.M. (2001) 'In Asia, its not a wide-open net', Wall Street Journal, 9 July, p.B1. 